\title{
Biogeochemical transformations of dissolved organic matter at the sediment-water interface: results from in situ incubations within benthic chambers
}

\author{
Alessandra Accornero ${ }^{\mathrm{a}, \mathrm{b}}, *$, Philippe Picon ${ }^{\mathrm{b}}$, Francis de Bovée ${ }^{\mathrm{c}}$ \\ a Istituto di Meteorologia ed Oceanografia, Università degli Studi Parthenope, via A. De Gasperi 5, 80133 Naples, Italy \\ ${ }^{\mathrm{b}}$ CEFREM, CNRS-Université de Perpignan, 52, avenue de Villeneuve, 66860 Perpignan cedex, France \\ 'Observatoire Océanologique de Banyuls-sur-Mer, CNRS-Université de Paris VI, 66651 Banyuls-sur-Mer cedex, France
}

Received 22 December 2001; received in revised form 17 June 2002; accepted 17 June 2002

\begin{abstract}
Biogeochemical transformations of dissolved organic matter at the sediment-water interface were investigated by the use of benthic chambers in the western Gulf of Lions. The experimental approach used for this study consisted of in situ incubations of radiolabeled glutamic acid $\left({ }^{14} \mathrm{C}\right.$-Glu), followed by a sequential extraction allowing the quantification of the radioactivity associated to different chemical fractions, representative of different biogeochemical processes. This technique was devised to simulate the fate of simple dissolved compounds resulting from the degradation of particulate organic matter near the seafloor. In our experiment the substrate underwent both biotic (mineralization, bacterial incorporation) and abiotic (geopolymerization) transformations. Significant spatial variations were put in relation with sediment characteristics (e.g. fine-grained fraction, Eh, $\mathrm{CaCO}_{3}$ contents) and biological activities, such as bacterial respiration and infaunal burrowing. Biologically mediated processes decreased from onshore to deep sites, with mineralization always accounting for the bulk of transformations of the injected ${ }^{14} \mathrm{C}-\mathrm{Glu}$. Geopolymerization did not display a clear spatial trend and appeared to be a quantitatively important process on the Gulf of Lions margin. (c) 2002 Ifremer/CNRS/IRD/Éditions scientifiques et médicales Elsevier SAS.
\end{abstract} All rights reserved.

\section{Résumé}

Les transformations biogéochimiques de la matière organique dissoute à l'interface eau-sédiment ont été étudiées à l'aide de chambres benthiques dans le secteur occidental du Golfe du Lion. L'approche expérimentale consistait en une incubation in situ d'acide glutamique marqué radioactivement $\left({ }^{14} \mathrm{C}-\mathrm{Glu}\right)$. Cette technique a été mise au point pour simuler l'évolution de composés dissous simples issus de la dégradation de la matière organique particulaire près du fond. Cet acide aminé a subi des transformations biotiques (minéralisation, incorporation bactérienne) et abiotiques (géopolymérisation). Des variations spatiales significatives ont été mises en relation avec les caractéristiques du sédiment (ex., fraction granulométrique fine, $\mathrm{Eh}$, contenu en $\mathrm{CaCO}_{3}$ ) et des activités biologiques telles que la respiration bactérienne et la bioturbation. Les processus biologiques montrent une diminution de la côte vers le large et la minéralisation est responsable de la plus grande partie des transformations du $\left({ }^{14} \mathrm{C}-\mathrm{Glu}\right)$ injecté. La géopolymérisation ne montre pas de tendance spatiale mais apparaît comme un processus quantitativement important sur la marge continentale du Golfe du Lion. (C) 2002 Ifremer/CNRS/IRD/Éditions scientifiques et médicales Elsevier SAS. Tous droits réservés.

Keywords: Sediment-waterinterface; Benthic chamber; In situ incubations; Continental margin; NW Mediterranean

Mots clés: Interface eau-sédiment; Chambre benthique; Incubation in situ; Marge continentale; Méditérranée nord-occidentale

\footnotetext{
* Corresponding author.

E-mail address: accornero@uninav.it; accorner@unina.it (A. Accornero).
} 


\section{Introduction}

The marine sediment-water interface is characterized by steep biological and physico-chemical gradients that foster changes in the nature and quantity of the deposited organic matter (OM) (Berner, 1980). Biogeochemical reactions taking place at the benthic boundary layer determine the rate of OM remineralization, which leads to nutrient and $\mathrm{CO}_{2}$ regeneration. The fraction of organic carbon (OC) that escapes oxidation processes is possibly buried and preserved within the sediment column, and thus lost for the ocean-atmosphere system over geological time scales (Hedges and Keil, 1995). Quantification of these reactions, as well as the elucidation of the individual processes involved, may significantly contribute to the understanding of the marine carbon cycle and is a matter of great interest not only to biogeochemists, but also to benthic biologists and geologists.

Continental margins, including the coastal area, shelf and slope, represent the link between continents and the open sea, and play a major role in the biogeochemical carbon cycle (Wollast, 1991; Bauer and Druffel, 1998). Coastal areas are important sites for OM deposition and early diagenesis (Henrichs, 1992; Hedges and Keil, 1995), resulting from enhanced biological production and OM transfer from the overlying euphotic layer (Jahnke et al., 1990). Up to $50 \%$ of primary production may be transferred to the seabed in this region, i.e. a much larger fraction as compared to $1-2 \%$ in the open ocean (Wollast, 1991).

The organic monomers originated from OM degradation represent the main source of carbon and energy to benthic heterotrophic organisms, which can mineralize them into dissolved inorganic carbon (IC) via respiration processes, or incorporate them into cellular constituents. Monomers can also undergo abiotic transformations, by random polymerization and consequent formation of humic substances (Rashid, 1985), i.e. highly refractory geopolymers and precursors of kerogens, which are responsible for a great part of the OC preservation (Tissot and Welte, 1984). Geopolymerization leads to the complexation of $\mathrm{OM}$ and may be the first step of its preservation in the sediment. Amino acids represent a significant part of OM in marine sediments and account for 40-90\% of the total nitrogen released by mineralization processes (Henrichs and Farrington, 1987). They have also been hypothesized to participate in the formation of humic substances through condensation reaction with carbohydrates (Larter and Douglas, 1980).

This experiment was part of the Banyuls Benthic Lander in the Gulf of Lions programme (BBLL), focused on studying the benthic biological activity and the chemical processes occurring at the sediment-water interface in the Gulf of Lions. Despite it representing only $5 \%$ of the northwestern Mediterranean margin, this area accounts for $30 \%$ of the overall sediment accumulation (Zuo et al., 1997). Sedimentary processes in the Gulf of Lions have been extensively studied in the last decade (Monaco et al., 1990; Gadel et al., 1992; Tahey et al., 1994; Buscail and Germain, 1997; Zuo et al., 1997; Picon et al., 2001; Accornero et al., in press).

The main aim of this study is to contribute to the knowledge of the processes that transform $\mathrm{OM}$ in the benthic boundary layer of this continental margin system. To attain this objective, we devised an original experimental approach based on in situ incubations of radiolabeled glutamic acid $\left({ }^{14} \mathrm{C}-\mathrm{Glu}\right)$ within benthic chambers, followed by a sequential extraction allowing the quantification of the radioactivity in different chemical fractions (representative of different biogeochemical processes). The technique described in this paper led us to identify the main pathways followed by dissolved OM during its evolution, by assessing the fractions that undergo mineralization or preservation. Glu was chosen to simulate the fate of simple dissolved compounds resulting from the degradation of particulate $\mathrm{OM}$ near the seafloor, because it is one of the quantitatively most important amino acids in marine sediments (Henrichs and Farrington, 1987; Sugai and Henrichs, 1992). Besides results of ${ }^{14} \mathrm{C}-\mathrm{Glu}$ incubations, OC mineralization rates, estimated via in situ measurements of sediment oxygen uptake, are presented. The ultimate objective of this study is to contribute to the understanding of organic compound turnover and early diagenesis in the benthic boundary layer.

\section{Materials and methods}

Four stations, located along an onshore-to-offshore transect in front of Banyuls-sur-Mer, in the southwestern part of the Gulf of Lions, were selected for our study (Table 1). Station 'Vases Terrigènes Côtières' (VTC), i.e. terrigenous coastal muds, was in the Bay of Banyuls, Station 'Vases du large' (VL), i.e. offshore muds, was on the adjacent shelf area, Stations 'interfluve' (INT2) and 'axis' (AXIS) were located in the interfluve and axis of the Lacaze-Duthiers canyon, respectively. Benthic chambers were deployed to measure sediment oxygen uptake rates and to perform in situ incubation experiments with ${ }^{14} \mathrm{C}$-Glu. Sediment samples were also recovered, to determine sediment characteristics such as redox potential, grain size, OC and carbonate $\left(\mathrm{CaCO}_{3}\right)$ contents.

Table 1

Location of benthic chamber deployment

\begin{tabular}{llllc}
\hline Station & Location & Latitude $(\mathrm{N})$ & Longitude $(\mathrm{E})$ & Depth $(\mathrm{m})$ \\
\hline VTC & Bay of Banyuls & $42^{\circ} 29.64^{\prime}$ & $03^{\circ} 09.54^{\prime}$ & 34 \\
VL & shelf & $42^{\circ} 30.52^{\prime}$ & $03^{\circ} 13.05^{\prime}$ & 85 \\
INT2 & open slope & $42^{\circ} 29.40^{\prime}$ & $03^{\circ} 29.80^{\prime}$ & 327 \\
AXIS & canyon axis & $42^{\circ} 27.72^{\prime}$ & $03^{\circ} 29.70^{\prime}$ & 910 \\
\hline
\end{tabular}




\subsection{Benthic chamber deployments and in situ incubations}

The Banyuls benthic lander is an autonomous apparatus that was designed in the Laboratoire Arago of Banyuls-surMer (a detailed technical description is given by Tengberg et al., 1995). It carries four benthic chambers that can be deployed down to a depth of $2000 \mathrm{~m}$. Each chamber is a stainless steel cylinder $\left(S=177 \mathrm{~cm}^{2}, H=32 \mathrm{~cm}\right)$, with internal walls covered by a non-toxic epoxy paint (Epodux 312 , Julien). Approximately $1 \mathrm{~h}$ after the lander had reached the sea floor, chambers penetrated into the sediment, isolating a portion of sediment surface overlaid by about 51 of in situ bottom water. A motor-driven stirrer $(30 \mathrm{rpm})$ maintained water movement inside each chamber, in order to prevent concentration gradients. Two of the four chambers were equipped with an oxygen probe (polarographic Clark type) that continuously measured the oxygen concentration in the overlying water. Sediment oxygen uptake was calculated from the slope of the linear decrease in oxygen concentration during the time of incubation (Hall et al., 1989). On the basis of previous experience, the incubation times were fixed at $12 \mathrm{~h}$ at St. VTC, $24 \mathrm{~h}$ at St. VL and $48 \mathrm{~h}$ at Sts. INT2 and AXIS. The final $\mathrm{O}_{2}$ concentration in the overlying water was $80-95 \%$ of the initial $\mathrm{O}_{2}$ concentration. In situ incubations of ${ }^{14} \mathrm{C}$-Glu were conducted by injecting U- ${ }^{14} \mathrm{C}-\mathrm{Glu}\left(400 \mu \mathrm{l}\right.$, specific activity $249 \mathrm{mCi} \mathrm{mmol}^{-1}$, Amersham Corp.) in the overlying water of two chambers (approximately $10 \mathrm{~cm}$ above the sediment), few minutes after the penetration of the chamber into the sediment. At the end of the incubation time, sediment and water were recovered from the chamber and immediately frozen for further processing in the laboratory.

\subsection{Sediment sampling and analyses}

Cores from chambers without ${ }^{14} \mathrm{C}$-Glu injections were used for the determination of sediment characteristics. Once on board, the lid of each chamber was removed, the overlying water was gently siphoned out and sediment cores were taken with plexiglas tubes. Each core was cut into $0.5 \mathrm{~cm}$ thick slices, which were stored separately in hermetic vials. Sediment was sieved through a $63 \mu \mathrm{m}$ net to separate silt and clays from sand. For the measurement of redox potential the plexiglas tube used to remove the core from the chamber was perfored every $0.5 \mathrm{~cm}$ and potential was measured by introducing a redox electrode (Ingold) connected to a pH-meter (Knick) into these holes. Total carbon (TC) content was analyzed by combustion of the dried sediment in a Leco CS 125 analyzer. For OC determination the combustion was performed after acidification with $2 \mathrm{~N} \mathrm{HCl}$ and subsequent drying. IC was calculated by difference ( $\mathrm{IC}=\mathrm{TC}-\mathrm{OC}$ ) and multiplied by a factor of 8.33 to estimate $\mathrm{CaCO}_{3}$ content, assuming that all IC was in the form of $\mathrm{CaCO}_{3}$.

\subsection{Geochemical extraction and ${ }^{14} \mathrm{C}$-radioactivity counting}

After ${ }^{14} \mathrm{C}$-Glu incubations, radioactivity in the overlying water and in the different geochemical fractions extracted from the sediment (Fig. 1) was counted with a Wallac 1409 liquid scintillation counter, after addition of a scintillation cocktail (Optiphase Hisafe III).

Bacterial cells were removed from the water by filtration through $0.2 \mu \mathrm{m}$ polycarbonate filters and the filter radioactivity was assumed to represent the ${ }^{14} \mathrm{C}$-Glu incorporated by bacteria. Radioactivity was then measured in the water, before and after removal of IC, by acidification to $\mathrm{pH} 1$ with $36 \% \mathrm{HCl}$ and bubbling. $\mathrm{T}^{14} \mathrm{CO}_{2}$-activity was calculated by difference. The sediment was submitted to the sequential chemical extraction described below (schematically represented in Fig. 1), which allowed recovery of the following fractions: (1) inorganic fraction; (2) acid-soluble fraction; (3) lipidic fraction; (4) alkali-soluble fraction; (5) fulvic and humic acids; (6) hydrolysable humin; (7) residual humin.

(1) Approximately $1 \mathrm{ml}$ of sediment was placed into a $150 \mathrm{ml}$ bottle that was hermetically sealed by a stopper, under which a nacelle containing a paper filter soaked with $200 \mu \mathrm{l}$ phenylethylamine was fixed. $\mathrm{HCl}(2 \mathrm{~N})$ was then injected through the stopper, to transform carbonate into volatile $\mathrm{CO}_{2}$, subsequently trapped by the phenylethy

\section{sequential extraction $\quad$ extracted fractions}

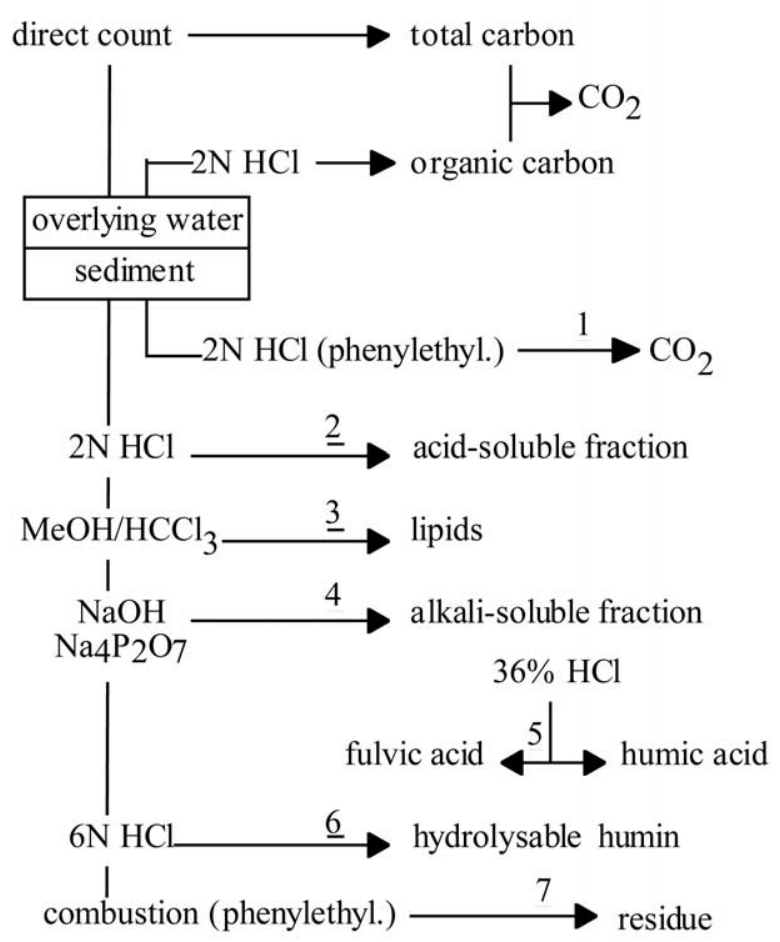

Fig. 1. Experimental procedure for the chemical extraction used in this study. Each number represents a step in the sequential extraction (see detailed explanation in the text, section 2.3.). 
lamine. After agitation $(24 \mathrm{~h})$, the radioactivity of the filter, accounting for the fraction of ${ }^{14} \mathrm{C}$-Glu mineralized during the experiment, was measured.

(2) To extract the acid-soluble fraction, $2 \mathrm{~N} \mathrm{HCl}$ was added to a sediment aliquot that was not used for step (1), until complete decarbonatation was reached. After agitation $(2 \mathrm{~h})$ and subsequent centrifugation, $1 \mathrm{ml}$ of the overlying aqueous phase was collected for radioactivity counting. The acid-soluble fraction contains the metabolites derived from the injected substrate, produced through biotic reactions (Gadel et al., 1983), or possibly the untransformed substrate itself (Cahet and Sibuet, 1986), dissolved in pore water or weakly adsorbed on carbonate and subsequently liberated by the acid treatment. The sediment was then rinsed, centrifugated and dried at $40{ }^{\circ} \mathrm{C}$ for $72 \mathrm{~h}$.

(3) A chloroform/methanol solution (2/1; vol.) was added to the dry sediment obtained from step (2) to extract the lipidic fraction (Blight and Dyer, 1959). After agitation (20 min), followed by centrifugation, $1 \mathrm{ml}$ of the liquid phase was collected for radioactivity counting.

(4) $\mathrm{NaOH}(0.1 \mathrm{~N})$ and $1 \% \mathrm{Na}_{4} \mathrm{P}_{2} \mathrm{O}_{7}$ were added to the sediment obtained from step (3), to extract the alkali-soluble fraction (Debyser and Gadel, 1983). After agitation (24 h) and subsequent centrifugation, supernatant was removed and $0.5 \mathrm{ml}$ was used for counting.

(5) The alkaline solution resulting from step (4) was acidified to $\mathrm{pH} 1$ by addition of $36 \% \mathrm{HCl}$, leading to the precipitation of humic acids (Langvik, 1994). After $12 \mathrm{~h}$, the solution was centrifugated and $1 \mathrm{ml}$ of supernatant was taken for counting. Humic acid radioactivity was obtained by substracting fulvic acid radioactivity from the radioactivity of the alkali-soluble fraction.

(6) An aliquot of the sediment issued from the alkaline extraction (step 4) was submitted to hydrolysis with $6 \mathrm{~N}$ $\mathrm{HCl}$ for $16 \mathrm{~h}$ at $110{ }^{\circ} \mathrm{C}$, in order to extract the hydrolysable humin. After centrifugation, $0.5 \mathrm{ml}$ of the supernatant was collected for counting.

(7) To evaluate the residual humin radioactivity, the sediment resulting from step (6) was combusted in an induction furnace (Leco CS 125). An oxygen flow, carrying the products of combustion, was bubbled in a tube filled with phenylethylamine; $1 \mathrm{ml}$ was collected for radioactivity counting. The residual humin, i.e. what resisted the previous treatments, includes polycondensation products totally insoluble and resistant to acid attack (Gadel et al., 1983), as well as macromolecules adsorbed between clay sheets. In our experiments this fraction was always quantitatively insignificant.

In the following chapters, we consider that the radioactivity associated to the inorganic fraction (step 1) is representative of mineralization, while the radioactivity included in the alkali-soluble fraction (i.e. fulvic + humic acids, step 5), hydrolyzable and residual humin (steps 6 and 7) stands for geopolymerization.

\section{Results}

\subsection{Sediment characteristics}

Sediment characteristics are displayed in Table 2. The most coastal site (St. VTC) was richer in terrigenous material and showed a coarser granulometry as compared to other stations. Visual observations of the sediment-water interface highlighted a peculiar appearance of St. VL: this site differed from the others due to the great number of infaunal burrows that characterized the sediment surface and first centimeters. OC and $\mathrm{CaCO}_{3}$ contents in the top $(0-2 \mathrm{~cm})$ sediment layer showed opposite trends, decreasing and increasing, respectively, from the most coastal site towards the slope. The depth at which redox potential becomes negative was located within the top $2 \mathrm{~cm}$ of sediment at the coastal and shelf stations (VTC and VL) and was significantly deeper on the slope (Sts. INT2 and AXIS).

\section{2. ${ }^{14} \mathrm{C}$-Glu mineralization and sediment oxygen uptake rates}

${ }^{14} \mathrm{C}$-Glu mineralization in the sediment varied spatially (Fig. 2), decreasing from the most coastal site offshore and showing lower rates on the open slope (St. INT2) than in the canyon axis (St. AXIS). Sediment oxygen uptake exhibited an identical trend, with minimal values recorded again at the interfluve site.

Table 2

Sediment characteristics

\begin{tabular}{lllll}
\hline Station & $\begin{array}{l}\mathrm{OC}(0-2 \mathrm{~cm}) \\
(\% \text { d.w. })\end{array}$ & $\begin{array}{l}\mathrm{CaCO}_{3} \\
(0-2 \mathrm{~cm}) \\
(\% \text { d.w. })\end{array}$ & $\begin{array}{l}\text { Mean redox }(*) \\
(\mathrm{mV})\end{array}$ & $\begin{array}{l}\text { Silt + clay } \\
(\%)\end{array}$ \\
\hline VTC & 0.94 & 13.5 & $-166(<1)$ & 76.7 \\
VL & 0.85 & 22.2 & $-5(2)$ & 94.7 \\
INT2 & 0.78 & 26.1 & $58(4)$ & 98.7 \\
AXIS & 0.81 & 24.9 & $112(>5)$ & 96.8 \\
\hline
\end{tabular}

(*) Depth $(\mathrm{cm})$ below which $\mathrm{Eh}<0$ is between brackets.

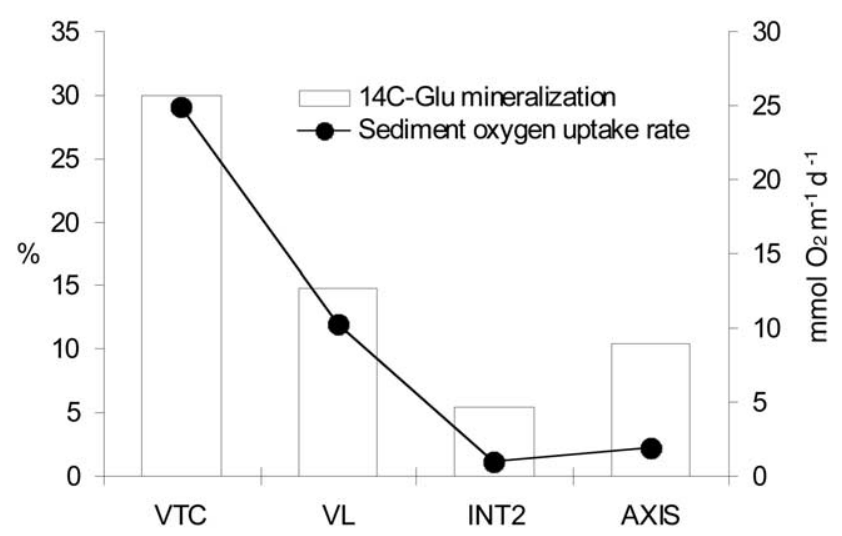

Fig. $2 .{ }^{14} \mathrm{C}-\mathrm{Glu}$ mineralization in the sediment (\% of total recovered radioactivity) and sediment oxygen uptake rates $\left(\mathrm{mmol} \mathrm{O}_{2} \mathrm{~m}^{-2} \mathrm{~d}^{-1}\right)$. 


\section{3. ${ }^{14} \mathrm{C}$-Glu partitioning in the sediment}

With the exception of St. VL, the radioactivity incorporated within the sediment did not exceed $38 \%$ of the total recovered radioactivity (St. VTC: 34\%; St. INT2: 38\%; St. AXIS 33\%) and penetrated down to a depth of $6 \mathrm{~cm}$. At St. VL, however, sediment radioactivity rose to more than $60 \%$ of the total, and penetration was limited at $5 \mathrm{~cm}$. Once in the sediment, the labeled substrate underwent a series of biogeochemical transformations, and its radioactivity distributed into chemically different fractions. The radioactivity partitioning in the different sedimentary fractions $\left(\Sigma^{14} \mathrm{CO}_{2}\right.$, acid-soluble, lipids, fulvic and humic acids, humin), expressed as the percentage of the total radioactivity recovered from the sediment, is presented in Fig. 3 for each sediment layer and for the upper $6 \mathrm{~cm}$ of seafloor (integrated value). The ${ }^{14} \mathrm{C}$-Glu mineralized in the sediment accounted for 5 (St. INT2) to $30 \%$ (St. VTC) of the bulk radioactivity that penetrated into the sediment and did not vary very much with sediment depth (Fig. 3). The acid-soluble fraction accounted for most of the sediment radioactivity, varying from $47 \%$ at St. VTC to $80 \%$ at St. INT2. The lipidic fraction was negligible, ranging between 1 and 3\%. The humic fraction (fulvic acid + humic acid) decreased with depth in the sediment and represented between 9 (St. INT2) and $18 \%$ (St. VL). Humin showed the same depthdependent pattern and varied from 5 (St. INT2) to $15 \%$ (St. AXIS).

\section{Discussion}

\section{1. ${ }^{14} \mathrm{C}$-Glu mineralization and sediment oxygen uptake}

In this study the mineralization of dissolved $\mathrm{OM}$ at the sediment-water interface was estimated by means of a two-fold approach: by measuring the rates at which oxygen is uptaken by sediments and by measuring the rates of ${ }^{14} \mathrm{C}$-Glu mineralization. Sediment oxygen uptake rates measured in this study appear consistent with measurements performed in other sites and seasons within the Gulf of Lions area (Tahey et al., 1994; Picon et al., 2001; Accornero et al., in press). The rate of oxygen uptake by sediments is representative of the total sediment oxygen consumption, which includes both biotic and abiotic pathways. Oxygen consumption at the sediment-water interface can result
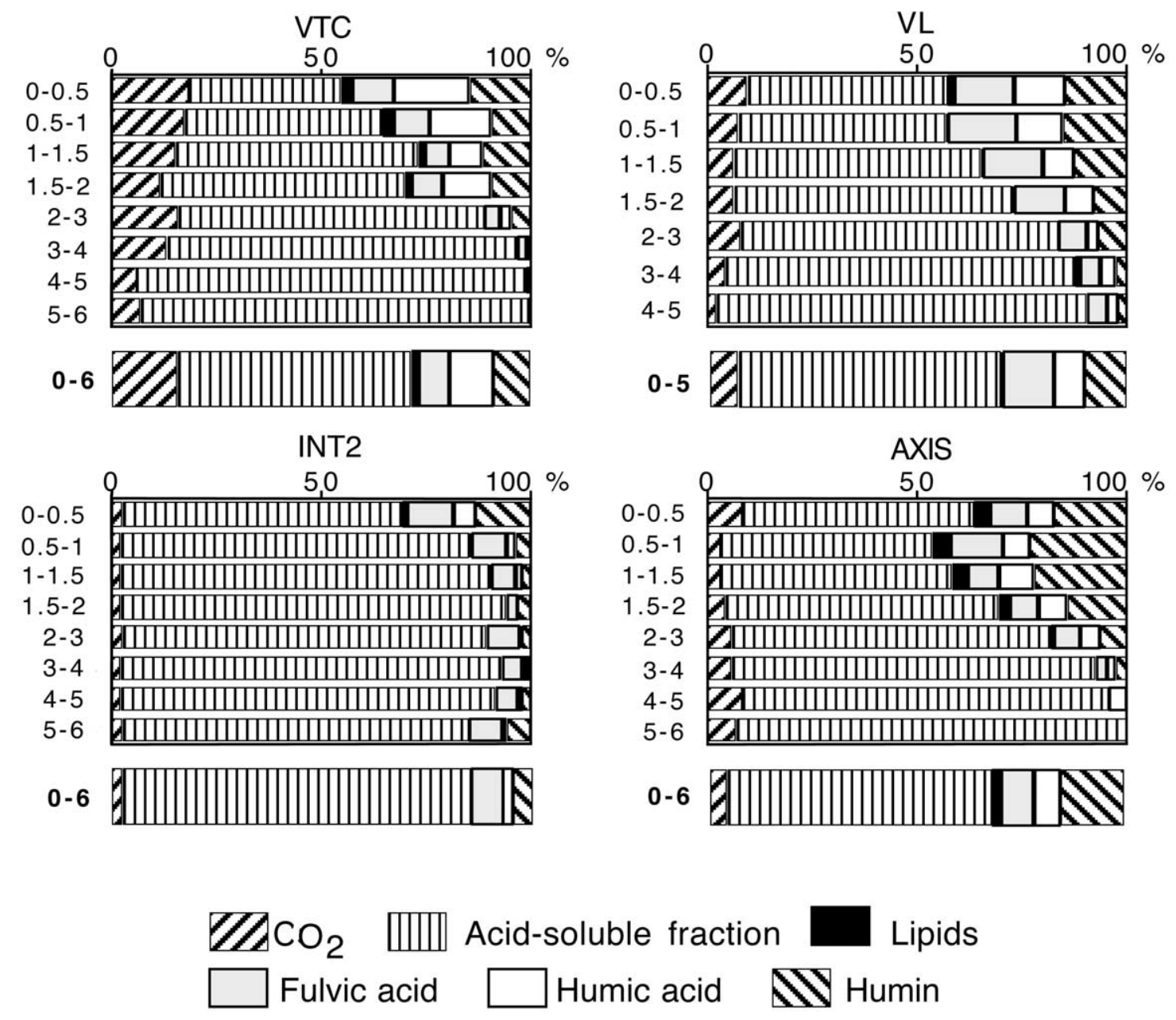

Fig. 3. Radioactivity partitioning in the geochemical fractions extracted from sediment. 
from the benthic community respiration and/or also from oxidation of reduced chemical species (Canfield et al., 1993). In our study the rates of oxygen consumption and carbon mineralization appear to be strictly related (Fig. 3). This suggests that oxygen is essentially consumed to oxidize OC, through biologically mediated reactions. Bacterial potential respiration measured at the sediment-water interface in the same sites of this study revealed that the rates of bacterial activity were strictly related to our ${ }^{14} \mathrm{C}$-Glu mineralization rates (Tholosan, 1999). This finding argues for Glu as a good proxy of the monomeric organic compounds used by heterotrophic benthic bacteria. The remineralization of $\mathrm{OC}$ in sediments is essentially mediated by the bacterial community (Deming and Baross, 1993), which directly takes up labile, low molecular weight molecules and hydrolyzes high molecular weight compounds via ectoenzymatic activity. Metazoan fauna and benthic foraminifera were also investigated in some of our stations and nearby sampling sites. A significant correlation was found between meiofaunal density and sediment oxygen uptake rates (Picon et al., 2001: $n=12, P<0.001$; Accornero et al., in press: $n=16$, $P<0.001)$. Similarly to meiofauna, the distribution of macrobenthos mirrored the spatial variations of oxygen uptake and carbon mineralization rates, with density decreasing with increasing depth and showing lower values on the open slope than in the canyon axis (Grémare, unpublished data). Standing stocks, distribution and microhabitat of benthic foraminifera were found to be related to oxygen uptake and food inputs from the overlying water (Schmiedl et al., 2000): in sites with higher food inputs the foraminiferal fauna exhibited higher standing stocks and diversities, epifaunal suspension-feeders dominated the community and oxygen consumption was enhanced. These observations underscore that both the density and specific composition of the benthic community can play an important role in OC mineralization. Benthic fauna tends to concentrate where more food is available, i.e. at aphotic depths, where more $\mathrm{OM}$ is supplied from the overlying water column. The rate of OM remineralization in marine sediments is related to carbon flux to the sediment surface, as demonstrated by (Henrichs, 1993) on the basis of a data set including results from 38 studies conducted between 1978 and 1992. The spatial and temporal pattern of OC remineralization in the northwestern Gulf of Lions was found to depend on the higher amount (see Heussner et al., 1996; Grémare et al., 1998) and the more labile nature (Buscail and Germain, 1997) of the OM reaching the seafloor of the shelf region (i.e. Sts. VTC and VL of this study) as compared to the continental slope (i.e. Sts. INT2 and AXIS) (Picon et al., 2001; Accornero et al., in press). Our data of Eh well match with these findings. The depth at which redox potential becomes negative increases with the distance from the coast (Table 2), suggesting that deposition rates of materials at the sediment surface decrease offshore. The shorter water column and the higher productivity in the euphotic layer (Lefèvre et al., 1997) undoubtedly play an important role in determining a higher input of fresh OM to shelf sediments, also resulting in a higher density of benthic organisms (De Bovée et al., 1990).

\subsection{Biogeochemical transformations of ${ }^{14} \mathrm{C}$-Glu}

In the study area the biogeochemical transformations of ${ }^{14} \mathrm{C}$-Glu exhibited both quantitative and qualitative variations. With the exception of St. VL, most of the injected radioactivity did not penetrate into the sediment and remained confined to the water phase, where a substantial fraction was mineralized (Fig. 2) and incorporated in bacterial cells (Fig. 4). At St. VL, however, the sediment radioactivity was nearly two times higher than at the other investigated sites. We believe that the higher proportion of radioactivity incorporated by sediments at this site was due to the peculiar sediment structure, resulting from the biological activity: at St. VL the seafloor was characterized by a great number of infaunal burrows (see section 3.1.). Active burrow irrigation inside the isolated chamber environment probably stimulated the transport of dissolved compounds according to their concentration gradient (Santschi et al., 1990).

From a qualitative viewpoint, in all stations and sediment layers the acid-soluble fraction accounted for the bulk of the radioactivity in the sediment, and tended to increase with sediment depth (Fig. 3). As mentioned above (section 2.3.), the acid-soluble fraction essentially includes the metabolites derived from microbial action upon the initially injected compound (Gadel et al., 1983) or possibly the untransformed substrate itself (Cahet and Sibuet, 1986). This latter is the most likely case in our experiment. Since Glu is sufficiently small to be taken up by bacteria without extracellular hydrolysis and be completely mineralized to $\mathrm{CO}_{2}$ once taken up, the radioactivity associated with the acid-soluble fraction is representative of the fraction of substrate that did not undergo any transformation. Glu molecules are known to weakly adsorb on sediment par-

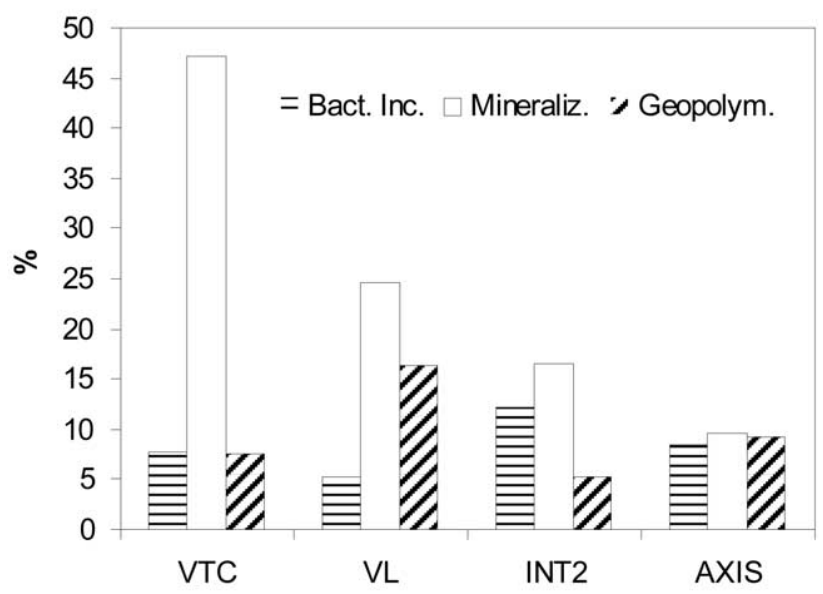

Fig. $4 .{ }^{14} \mathrm{C}-$ Glu bacterial incorporation, mineralization and geopolymerization in the benthic chamber. 
ticles, showing greater affinity for small-sized materials with high inorganic content (Gadel et al., 1983). At St. INT2, the higher proportion of ${ }^{14} \mathrm{C}-\mathrm{Glu}$ that remained untransformed during incubation (Fig. 3) is consistent with the predominant sediment characteristics: this station showed the finest granulometry $(99 \%$ of particles $<63 \mu \mathrm{m})$ and the highest $\mathrm{CaCO}_{3}$ content (26\% d.w.) (Table 2).

The second quantitatively most important sedimentary fraction was the humic pool (Fig. 3), i.e. the sum of humin + fulvic acid + humic acid. Humic compounds accounted for a relatively high proportion of the total recovered radioactivity at all sites (23-28\%), with the exception of St. INT2 (14\%), where adsorption onto mineral particles (see above) probably played a role in substracting a part of the injected compound initially available for geopolymerization processes.

In terms of processes, mineralization, in both the water and sediments, always accounted for the bulk of transformations of the injected ${ }^{14} \mathrm{C}-\mathrm{Glu}$, averaging $25 \%$ of the recovered radioactivity (Fig. 4). The part of substrate incorporated into bacterial cells was, on average, $8 \%$ (Fig. 4). Biologically mediated processes showed a spatial gradient: their importance globally decreased from onshore to deep sites, reflecting the abundances of heterotrophs (primarily bacteria and meiofauna) and ultimately the quantity and quality of OM inputs to the seafloor. Abiotic processes, such as geopolymerization, on the contrary, did not display a clear spatial trend and accounted for a more steady percentage of the total ${ }^{14} \mathrm{C}-\mathrm{Glu}$ transformations. Enhanced geopolymerization at St. VL (Fig. 4) was probably a mere consequence of the higher fraction of radioactivity, which was allowed to penetrate into the sediment through the great number of burrows characterizing this site. On the whole, geopolymerization in surficial sediments appeared as a quantitatively important process in the Gulf of Lions margin, accounting, on average, for $10 \%$ of the transformations of the injected substrate.

In situ incubation of ${ }^{14} \mathrm{C}-\mathrm{Glu}$ within benthic chambers proved to be a useful tool, which contributes to a better comprehension and quantification of biogeochemical transformations in the benthic boundary layer. OC transformations occurring at the sediment-water interface on the Gulf of Lions continental margin showed significant spatial variations, in relation to sediment characteristics (e.g. finegrained fraction, $\mathrm{CaCO}_{3}$ contents) and biological activities (e.g. bacterial respiration, infaunal burrowing). The similar trends of ${ }^{14} \mathrm{C}$-Glu mineralization and oxygen uptake, and their strict relation to the rates of bacterial potential respiration, argue for Glu as a good proxy for the activity level of heterotrophic benthic bacteria. Although meiofaunal densities, foraminiferal standing stock and diversity were found to be related to the rates of $\mathrm{OC}$ mineralization, further investigations are needed to clarify the role of benthic fauna in the uptake and transformations of dissolved labile compounds.

\section{Acknowledgements}

The authors are grateful to Roselyne Buscail, who provided helpful guidance and suggestions, and to $\mathrm{A}$. Khripounoff and an anonymous referee for constructive review. This research was undertaken in the framework of the Mediterranean Targeted Project phase II Mater and of the French PNOC (Programme National d'Océanographie Côtière). We acknowledge the support from the European Commission's Marine Science and Technology Programme (Mast III) under contract MAS3-CT96-0051. We are grateful to the captain and crew of the R/V Europe (Ifremer) and Tethys II (Insu) for their helpful cooperation.

\section{References}

Accornero, A., Picon, P., de Bovée, F., Charrière, B., Buscail, R., date? 00. Organic carbon budget at the sediment-water interface on the Gulf of Lions continental margin. Cont. Shelf Res (in press).

Bauer, J.E., Druffel, E.R.M., 1998. Ocean margins as a significant source of organic matter to the deep open ocean. Nature 392, 482-485.

Berner, R.A., 1980. Early Diagenesis: a Theoretical Approach. Princeton University Press, Princeton p. 241.

Blight, E.G., Dyer, W.J., 1959. A rapid method of total lipid extraction and purification. Can. J. Biochem. Phys. 37, 911-917.

Buscail, R., Germain, C., 1997. Present-day organic matter sedimentation on the NW Mediterranean margin: importance of the shelf export. Limnol. Ocenanogr. 42, 217-229.

Cahet, G., Sibuet, M., 1986. Activité biologique en domaine profond : transformations biochimiques in situ de composés organiques marqués au carbone-14 à l'interface eau-sédiment par $2000 \mathrm{~m}$ de profondeur dans le Golfe de Gascogne. Mar. Biol. 90, 307-315.

Canfield, D.E., Jørgensen, B.B., Fossing, H., Glud, R., Gundersen, J., Ramsing, N.B., et al., 1993. Pathways of organic carbon oxidation in three continental margin sediments. Mar. Geol. 113, 27-40.

De Bovée, F., Guidi, L.D., Soyer, J., 1990. Quantitative distribution of deep-sea meiobenthos in the northwestern Mediterranean (Gulf of Lions). Cont. Shelf Res. 10, 1123-1145.

Debyser, Y., Gadel, F., 1983. Géochimie des kérogènes dans les sédiments. Géochimie organique des sédiments marins. D'Orgon à Misedor. CNRS, Paris, pp. 421-450.

Deming, J.W., Baross, J.A., 1993. The early diagenesis of organic matter: bacterial activity. In: Engel, M.H., Macko, S.A. (Eds.), Organic Geochemistry. Principles and Applications. Plenum Press, New York, pp. 119-144.

Gadel, F., Buscail, R., Cahet, G., 1983. Réactivité de dépôts marins profonds au contact de composés organiques marqués: processus biogéochimiques. Géochimie organique des sédiments marins, D'Orgon à Misedor. CNRS, Paris, pp. 73-98.

Gadel, F., Charrière, B., Serve, L., Tomellas, L., 1992. Caractérisation chimique des substances humiques et de leurs classes de poids moléculaires dans les dépôts superficiels du delta du Rhône: relation avec leur origine et les conditions du milieu. Oceanol. Acta 15, 61-74.

Grémare, A., Amouroux, J.M., Charles, F., Medernach, L., Jordana, E., Nozais, C., et al., 1998. Temporal changes in the biochemical composition of particulate organic matter sedimentation in the Bay of Banyuls-sur-Mer. Oceanol. Acta 6, 783-792.

Hall, P.O.J., Anderson, G., Rutgers Van Der Loeff, M.M., Sunby, B., Westerlund, S.F.G., 1989. Oxygen uptake kinetics in the benthic boundary layer. Limnol. Oceanogr. 34, 734-746.

Hedges, J.I., Keil, R.G., 1995. Sedimentary organic matter preservation: an assessment and speculative synthesis. Mar. Chem. 49, 81-115. 
Henrichs, S.M., 1992. Early diagenesis of organic matter in marine sediments: progress and perplexity. Mar. Chem. 39, 119-149.

Henrichs, S.M., 1993. Early diagenesis of organic matter: the dynamics (rates) of cycling of organic compounds. In: Engel, M.H., Macko, S.A. (Eds.), Organic Geochemistry. Principles and Applications. Plenum Press, New York, pp. 101-117.

Henrichs, S.M., Farrington, J.W., 1987. Early diagenesis of amino acids and organic matter in two coastal marine sediments. Geochim. Cosmochim. Acta 51, 1-15.

Heussner, S., Calafat, A.M., Palanques, A., 1996. Quantitative and qualitative features of particle fluxes in the North-Balearic basin. In: Canals, M., Casamor, J.L., Cacho, I., Calafat, A.M., Monaco, A. (Eds.), EUROMARGE-NB Final Report, MAST II Programme, vol. II. University of Barcelona, pp. 41-66.

Jahnke, R.A., Reimers, C.E., Craven, D.B., 1990. Intensification of recycling of organic matter at the sea floor near ocean margins. Nature $348,50-54$.

Langvik, V., 1994. Characterization of aromatic structures in humic and fulvic acids. Environ. Int. 20, 61-65.

Larter, S.R., Douglas, A.G., 1980. Melanoidins-kerogen precursors and geochemical lipid sinks: a study using pyrolysis gas chromatography (PGC). Geochim. Cosmochim. Acta 44, 2087-2095.

Lefèvre, D., Minas, H.J., Minas, M., Robinson, C., Williams, P.J., Le, B., et al., 1997. Review of gross community production, primary production, net community production and dark community respiration in the Gulf of Lions. Deep-Sea Res. II 44, 801-832.

Monaco, A., Biscaye, P.E., Pocklington, R., 1990. France-JGOFS, ECOMARGE, particle fluxes and ecosystem response on a continental margin. Cont. Shelf Res. 10 (special issue), 1155.

Picon, P., Accornero, A., de Bovée, F., Charrière, B., Buscail, R., 2001. Sediment community oxygen consumption along a shelf-slope transect in the western Gulf of Lions. In: Faranda, F.M., Guglielmo, L., Spezie, G. (Eds.), Structures and Processes in the Mediterranean Ecosystems. Springer-Verlag. pp. 407-413.
Rashid, M.A., 1985. Geochemistry of marine humic compounds. SpringerVerlag, New York.

Santschi, P.H., Höhener, P., Benoit, G., Buchholtz-Ten Brink, M., 1990. Chemical processes at the sediment-water interface. Mar. Chem. 30, 269-315.

Schmiedl, G., de Bovée, F., Buscail, R., Charrière, B., Hemleben, C., Medernach, L., et al., 2000. Trophic control of benthic foraminiferal abundance and microhabitat in the bathyal Gulf of Lions, western Mediterranean Sea. Mar. Micropal. 40, 167-188.

Sugai, S.F., Henrichs, S.M., 1992. Rates of amino acid uptake and mineralization in Resurrection Bay (Alaska) sediments. Mar. Ecol. Prog. Ser. 88, 129-141.

Tahey, T.M., Duineveld, G.C.A., Berghuis, E.M., Helder, W., 1994. Relation between sediment-water fluxes of oxygen and silicate and faunal abundance at continental shelf, slope and deep-water stations in the northwest Mediterranean. Mar. Ecol. Prog. Ser. 104, 119-130.

Tengberg, A., de Bovée, F., Hall, P., Berelson, W., Chadwick, B., Ciceri, G., et al., 1995. Benthic chamber and profiling lander in oceanography-a review of design, technical solutions and functioning. Prog. Oceanogr. 35, 253-294.

Tholosan, O., 1999. Activités microbiennes dans les eaux et les sédiments profonds. Rôle de la pression hydrostatique. Ph.D. thesis. Université de la Méditerranée, Aix-Marseille II, France p. 275.

Tissot, B.P., Welte, D.H., 1984. Petroleum formation and occurrence. second ed. Springer-Verlag, Heidelberg.

Wollast, R., 1991. The coastal organic carbon cycle: fluxes, sources, and sink. In: Mantoura, R.F.C., Martin, J.M., Wollast, R. (Eds.), Ocean Margin Processes in Global Change. John Wiley and Sons, New York, pp. 365-381.

Zuo, Z., Eisma, D., Gieles, R., Beks, J., 1997. Accumulation rates and sediment deposition in the northwestern Mediterranean. Deep-Sea Res. II 44, 597-609. 